\title{
MISTURAR E CIRCULAR EM MODULAÇÕES GUARANI. UMA ETIOLOGIA DAS (IN)DISPOSIÇÕES *
}

\author{
Valéria Macedo
}

Xeretã mombyry, ndavy'ai. Avaka porã repoxi nda'uxeire.

[Meu lugar é longe, não me acostumo. Não quero comer estrume de um belo gado.]

(Trecho de canção guarani registrada por Schaden na Serra do Mar em 1946) ${ }^{1}$

\section{O texto e suas misturas}

Quando iniciei minha pesquisa de doutorado, em 2005, fui ao encontro dos Guarani buscando acompanhar sua inserção no universo de projetos, políticas e eventos voltados para populações indígenas, os quais vinham se multiplicando desde a Constituição de 1988. Minha questão era entender a relevância crescente da cultura como um idioma nas relações institucionalizadas com os brancos, e os efeitos de sua vinculação a diferentes imaginações conceituais. Centrei minha experiência de campo na Terra Indígena Guarani do Ribeirão Silveira, próxima à praia de Boraceia, no litoral paulista. Desde o final dos anos 1980, com a conclusão da pavimentação da rodovia Rio-Santos, a região até então considerada um "vazio demográfico" (por ser esparsamente habitada por índios e caiçaras) converteu-se no principal polo turístico do estado de São Paulo. Os Guarani foram ali me ensinando que, mais relevante do que aquilo que chamamos cultura, era no corpo, na doença, que experimentavam (e conceituavam) mais intensamente a alteridade dos brancos e outras relações de diferença. Este texto resulta de uma maturação (ou matutação) desse aprendizado. 
A corporalidade como idioma incontornável em socialidades ameríndias vem mobilizando reflexões etnológicas pelo menos desde o artigo seminal de Seeger, DaMatta e Viveiros de Castro (1979). A intenção aqui é fazer ressoar modulações ${ }^{2}$ guarani acerca de temas pungentes nessa literatura, como alteridade, afinidade e predação. Compondo uma etiologia de disposições e indisposições nos corpos, remeto a conceituações guarani sobre o que mistura e o que circula entre pessoas/gentes, com seus efeitos transformacionais e dimensões fractais, em que o entre pode ser também intracorporal.

Minhas interlocuções voltam-se para populações que vivem no estado de São Paulo, mas estão vinculadas a redes de aldeias que abrangem outras regiões, principalmente no sul e sudeste do país. No que concerne à etnologia guarani, priorizei diálogos com etnografias em aldeias na região Sudeste. A especificidade dessas conexões - considerando a vastidão dos mundos guarani - certamente produziu efeitos nas misturas que singularizam este texto.

Segundo dados de 2016 do Mapa Guarani Continental, ${ }^{3}$ populações guarani somam mais de 280 mil pessoas na Argentina (54.825), Bolívia (83.019), Brasil (85.255) e Paraguai (61.701). No Brasil, a divisão em três subgrupos guarani-falantes foi proposta por Schaden (1974 [1954]). Nandeva, Mbüa e Kayova, posteriormente grafados de modos alternativos (Nhandeva/ Nhandewa, Mbya, Kaiova/Kaiowa), guardariam entre si especificidades dialetais, culturais e históricas. Enquanto os Kaiova estão em sua grande maioria concentrados no Mato Grosso do Sul e no Paraguai, as aldeias mbya são predominantes nas regiões Sul e Sudeste do Brasil (com exceção de Minas Gerais), havendo ainda algumas famílias no Tocantins e Pará, além da população em Misiones/Argentina e Paraguai. Já os Nhandeva estariam presentes tanto nas regiões ocupadas pelos Kaiova como pelos Mbya.

No estado de São Paulo, a população classificada como Nhandeva costuma autodesignar-se como Tupi ou Tupi Guarani. ${ }^{4}$ Segundo levantamento de Veiga a partir de dados da Funai (2013:72-4), São Paulo em 2013 contava com 45 aldeias guarani e tupi guarani, somando uma população de aproximadamente 3.600 pessoas. Desse conjunto, 14 aldeias possuíam um contingente majoritário ou significativo de tupi guarani, sendo as demais de maioria guarani-mbya.

A discussão inicial a que se propõe este texto volta-se para tais tipologias étnicas, como subgrupos ou parcialidades, e sua problematização a partir de elaborações guarani. Nexos envolvendo aqueles classificados na literatura antropológica como subgrupos Mbya e Nhandeva ${ }^{5}$ apresentaram-se como questão à minha experiência etnográfica desde o início da pesquisa de doutorado. Na TI Ribeirão Silveira vivem cerca de 50 famílias, ${ }^{6}$ em boa parte compostas por casamentos entre membros associados a ambos os 
subgrupos, cuja descendência é bilateral. Muitos de meus interlocutores, contudo, não estavam familiarizados com esta classificação, já que todos costumam autodesignar-se com expressões pronominais como nhandeva ("aqueles que somos nós") ou nhandekuery ("nossa gente/coletividade"), ${ }^{7}$ não associando "Nhandeva" a apenas um subgrupo. ${ }^{8}$

Nas interlocuções com os brancos, os chamados Mbya também não costumavam usar essa autodesignação quando iniciei meu campo no Silveira, e sim Guarani. Como mencionado, os chamados Nhandeva - não apenas no Silveira, mas em aldeias no litoral sul e no sudeste do estado de São Paulo - em sua maioria não se identificam como Guarani e sim como Tupi, ou Tupi Guarani, reconhecendo como seus ancestrais os Tupi que habitavam a região quando os europeus chegaram. Seus sobreviventes foram se casando com os Guarani que vieram depois, bem como com descendentes dos europeus e africanos.

Os Guarani e os Tupi Guarani reconhecem-se como falantes de línguas distintas, mas aparentadas, e identificam diferentes modulações afectivas ${ }^{9}$ em seus corpos. Entre estas, costumam destacar uma maior disposição entre os Tupi para lutas e alianças, contrastando com a tendência entre os Guarani de evitarem o conflito aberto e serem mais reservados, preferindo partir a submeter-se aos outros ou confrontá-los diretamente. O texto buscará abordar como tais diferenças não se baseiam em premissas multiculturalistas, e sim no que podem os corpos, numa etiologia de suas composições e disposições. Por sua natureza relacional e cosmopolítica, ${ }^{10}$ tais disposições remetem a limiares de intensidade ${ }^{11}$ que variam de acordo com encontros intra e entre corpos, não se adequando, portanto, a estabilizações classificatórias.

Nessa direção, relações de afinidade envolvendo Guarani e Tupi são tematizadas, assim como variações situacionais no modo como pessoas vinculam-se a tais posições. Também será abordado o casamento com brancos, recorrente nas aldeias de maioria tupi no estado de São Paulo e idealmente interdito nas aldeias de maioria guarani. Dada a proximidade dos não indígenas, misturar ou circular são alternativas existenciais entre essas populações, mas são também movimentos mutuamente implicados. As misturas estão sempre acontecendo e envolvendo uma multiplicidade de seres, de modo que a circulação seria a busca de recomposição em outras misturas, a depender do que podem os corpos.

Em seguida, o texto aborda como a posição de sujeito implica o manejo desses movimentos em diferentes dimensões relacionais entre os Guarani (almas em corpos, pessoas em arranjos familiares, famílias em aldeias, pessoas ou coletivos em cidades etc.). Fortemente vinculada ao não se acostumar (ndovy'ai, cujos significados também podem ser "infelicidade", "saudades", 
entre outros), a circulação guarani-mbya remete a equacionamentos singulares entre fazer parentesco e diferença. Em meio a uma rede de aldeias dispersas num vasto território entrecortado por cidades, estradas, fazendas, parques e outras cercas, não há implicação necessária entre distância espacial e desaparentamento, tampouco entre proximidade e consanguinização, como ocorre entre outros ameríndios.

No que diz respeito às misturas, os Guarani enfatizam a condição tekoaxy ("viver-sofrer") dos viventes nesta terra, sempre oscilando entre o adoecimento e o fortalecimento como efeitos de relações. A afecção ou sofrimento (axy) como condição de existência (teko) dos corpos é então interseccionada à predação como estética ${ }^{12}$ ameríndia no agenciamento da diferença, em que a incorporação de potências exteriores a um só tempo constitui e desestabiliza a posição de sujeito, dada a implicação entre alteridade e alteração (Viveiros de Castro 1996).

Na seção final, o artigo busca ressonâncias no debate contemporâneo acerca de contramestiçagens (Goldman 2015) ou antimestiçagens (Kelly 2016) na antropologia, desestabilizando pressupostos identitários predominantes em nosso universo conceitual, seja pelo viés da purificação, que demoniza a mistura, seja pelo sincretismo, em que a mistura promoveria a estabilização das diferenças num repertório híbrido ou em um produto único. Como espero argumentar, tal etiologia guarani das misturas e seus efeitos nos corpos aponta para outras engrenagens do diferir.

\section{Disposições canibais e indisposições patogênicas}

Começo com a história que ouvi de Tata'i, moradora da TI Ribeirão Silveira, quando conversávamos sobre diferenças entre os Guarani e os Tupi. Ela remeteu à chegada dos jurua - modo recorrente de os Guarani nas regiões Sul e Sudeste referirem-se aos não indígenas - na colonização do que viria a ser o Brasil. Em meio a muitas guerras, os jurua foram chegando naquele litoral e matando os Tupi que ali viviam. Mas os que sobreviveram tiveram facilidade em casar-se com brancos, pois, sendo guerreiros canibais, seu sangue já era misturado com o de inimigos e por isso aguentavam o sangue jurua, não adoecendo com essas uniões. Os Tupi foram também casando com africanos que vieram escravizados e seus descendentes, e ainda com os Guarani que foram chegando, vindos do centro da terra (yvy mbyte), no Paraguai. ${ }^{13}$ 
Por sua vez, os Guarani jamais tiveram essa facilidade em casar-se com jurua, e a explicação de Tata'i é recorrente nas aldeias, remetendo à pureza do sangue, que o faz vulnerável a essa mistura, podendo adoecer ou matar a pessoa, ou alguém próximo a ela. ${ }^{14}$ Uniões são por isso interditas ou controversas, com intensidade variável a depender da aldeia, da família ou do cônjuge jurua em questão. Elas não deixam de ocorrer, mas costumam ser associadas a infortúnios de parentes ou corresidentes da pessoa que misturou seu sangue e teve filho com jurua.

A afecção jurua é ainda mais deletéria entre os karai ("líderes espirituais", em tradução mbya). Karai Tataendy, no Silveira, contou-me que muitos jurua nem sabiam da existência dos karai porque eles pouco saíam das opy (traduzidas como "casas de reza"). Seus xondaro (assistentes, mensageiros, guerreiros, guardiões) ${ }^{15}$ é que entravam e saíam, agenciando o mundo sob sua orientação. Também no Silveira, Karai Papa Mirĩ comentou que Nhanderu ("Nosso pai", aqui em referência ao demiurgo) queria que os Guarani fossem mesmo poucos, por isso fez os índios canibais para que protegessem os Guarani dos animais predadores e mais tarde dos brancos. Nessa direção, Wera Tupã comenta que antigamente os Tupinambá eram os guardiões dos Guarani (Ladeira \& Wera Tupã 2004:52). A mesma associação é destacada por Mello (2007:61) em relação aos Nhandeva, sendo estes aproximados aos xondaro e os Mbya aos karai. Tais populações concebem-se assim enredadas, reconhecendo a implicação mútua das posições de karai e xondaro em diferentes configurações relacionais.

Nas falas em Guarani, tanto aqueles que vivem na região Sul do país e são classicamente designados na antropologia como Nhandeva como os Tupi Guarani em São Paulo costumam ser designados como Xiripa pelos Mbya, em referência ao traje de algodão retangular antigamente usado entre as pernas ou nos ombros (Schaden 1974:31). Schaden comenta que os Nhandeva chamavam os Mbya de Tambeope, variação mais larga dessa vestimenta (:3). Além de Tambeope, os Mbya diferenciavam-se entre si por designações contextuais como Irari, Iraity, entre outras, que não remetiam a uma totalidade étnica. Ao mencionar tais agrupamentos, seus descendentes hoje costumam reconhecer-se como uma composição deles, reiterando seu enredamento.

Assim, mesmo que hoje a maioria adote o termo Mbya como autodesignação - e que este seja difundido na etnologia, incluindo este artigo - muitos Guarani atribuem aos brancos sua veiculação como nome de um povo ou de um subgrupo. Interlocutores de Ladeira (2007:25) apontaram que mbya era o modo como se referiam a visitantes de outras aldeias. A esse respeito, Mello (2007:61) comenta que a disseminação da terminologia Mbya pode 
estar associada à maior mobilidade dessas famílias pelas aldeias. Por sua vez, um interlocutor de Pierri (2013:23-4) explica que mbya é como se referiam a possíveis afins, condição de muitos dos visitantes que circulavam nessa rede.

É significativo o esforço de Mello em debater a nomenclatura desses subgrupos junto a professores e lideranças guarani, pois o resultado é o mapeamento de controvérsias que explicitam a impossibilidade de qualquer estabilização classificatória. Remetendo ao que Sáez designou como associologias ameríndias (2016:165), o caráter discreto, ou extensivo, atribuído aos subgrupos e quaisquer etnônimos fracassa em razão da natureza intensiva ${ }^{16}$ desses nomes, que operam individuações indissociáveis de configurações relacionais e seus agenciamentos.

Em 1946, quando esteve na Serra do Mar, Schaden (1974) registrou a presença de três aldeias guarani, duas delas de maioria Nhandeva (Itariri, em Itariri/SP, e Bananal, em Peruíbe/SP) e uma de maioria Mbya (Rio Branco, em Itanhaem/SP). Segundo o autor, os Nhandeva seriam descendentes de agrupamentos cujas migrações foram registradas por Nimuendaju (1987 [1914]), oriundas da região fronteiriça entre o Mato Grosso do Sul e o Paraguai, passando pelo centro-norte do Paraná e então pelo litoral-sul paulista. A despeito de não reconhecerem essas designações, os habitantes do Itariri descenderiam dos Tañiguá, chegados na década de 1820, e no Bananal viveriam também os descendentes dos Oguahuíva e Apapokúva, que vieram respectivamente nos anos 1820 e 1870. Mas a maioria dos moradores do Bananal provavelmente descenderia de um grupo chegado em 1885.

Schaden destaca a forte interação dos Nhandeva com "caboclos" da região, incluindo alguns casamentos e corresidência na aldeia do Bananal (1974:6). Tais "caboclos" provavelmente eram descendentes da população nativa dali, de origem tupi. Na visão de Schaden, eles já haviam sucumbido ao "processo aculturativo"17 e "não há remanescentes dos antigos Tupi da costa, desaparecidos já no período colonial" (:4). Mas o autor destaca que os Guarani costumavam chamar de "Tupinambá" aqueles de "tribo desconhecida" (:4).

A seu turno, Danaga aponta que muitos Tupi Guarani hoje se referem aos indígenas que sempre viveram na região como praianos, a exemplo deste comentário de Awá, cacique na aldeia Renascer (Ubatuba/SP): "os Tupi, na verdade, são os praianos de antigamente. Era que misturava, chamava de praiano, mas na verdade era tudo índio Tupi" (citado em Danaga 2016:52).

O karai Jejoko - a quem conheci no Silveira, crescido na aldeia do Bananal e falecido em 2012 - apresentava-se como um legítimo Tupinambá, tendo presenciado em sonho muitas guerras na praia de São Vicente na época da chegada dos portugueses. Dizia ainda que era afilhado de José 
de Anchieta. Mas contou-me também que sua mãe nascera de uma relação entre sua avó e um jurua - o que não contradizia, e sim reiterava, sua condição de legítimo Tupinambá (afeito à mistura).

Schaden também esteve na região Sudeste do estado, na Reserva de Araribá, posteriormente rebatizada de Nimuendaju, já que este a fundara em 1910, como membro do recém-inaugurado Serviço de Proteção aos Índios. A intenção de Nimuendaju era reunir os Guarani dispersos na região de modo a protegê-los de conflitos, sobretudo fundiários, em suas andanças rumo à costa sudeste. Poucos aceitaram ficar na reserva, muitos ali adoeceram e, dentre os sobreviventes, muitos fugiram posteriormente para a Serra do Mar (Ladeira \& Azanha 1988; Macedo 2009). Em 1947, Schaden afirma ter encontrado ali 78 Nhandeva, em sua maioria descendentes dos Apapokúva, e mestiços.

Já a aldeia mbya teria sido formada com membros oriundos do leste paraguaio e nordeste argentino, que atravessaram os estados do sul do Brasil até chegarem ao litoral paulista por volta de 1925. Ali viveram um tempo com os Nhandeva no Bananal até fundarem a aldeia Rio Branco. Quando esteve junto aos Guarani na Serra do Mar, em 1946, Schaden também testemunhou a chegada de um agrupamento mbya originário do leste do Paraguai, que nos anos 1940 estava vivendo no Rio Grande do Sul. ${ }^{18} \mathrm{O}$ autor destaca o fechamento dos Mbya aos brancos, tanto em relações de afinidade como na vida cerimonial e cotidiana na aldeia. Mas comenta suas incursões frequentes aos centros urbanos da região, principalmente São Vicente e São Paulo, onde angariavam doações e vendiam plantas e artesanato (1974:55).

Para além dos agrupamentos e aldeamentos apontados por Nimuendaju e posteriormente por Schaden, baseado em sua breve estadia em 1946, os Guarani, os Tupi e outros descendentes de povos nativos vinham há muito habitando e circulando naquela região sem que houvesse registro de sua existência. A ausência de malha viária e a escassa titulação de terras faziam com que a Serra do Mar fosse considerada um "vazio demográfico" até pelo menos meados do século XX (Cherobim 1986). Contudo, como expressa Benedito Calixto, em depoimento de 1903, este suposto "vazio" nunca deixou de ser povoado:

todo esse sertão, quase inculto e desabitado, [...] é ainda hoje constantemente percorrido por essa tribo de Guainá [sic: Guarani] nas suas idas e vindas para o litoral. [...] Aí estão eles verdadeiramente "em sua casa"; toda essa região é inteiramente despovoada, ninguém os incomoda, a não ser algum caçador que uma ou outra vez penetra nessas florestas (citado em Pierri et al. 2013:4). 
A partir de meados do século XX, cada vez mais famílias e pessoas nos estados da região Sul vieram chegando à costa sudeste e formando novas aldeias, de modo que a população classificada como Mbya foi se tornando mais numerosa do que a classificada como Nhandeva (Ladeira \& Azanha 1988). Esta, por sua vez, autodesignava-se como Tupi no estado de São Paulo, conforme testemunhou Cherobim (1986) já nos anos 1970. Ainda segundo o autor, tais populações também se diferenciavam como os "do Rio Grande" ou "do Paraná" (em vez de Mbya) e os "do litoral" (em vez de Nhandeva). Seja como for, tanto Cherobim como Ladeira e Azanha destacam a grande circulação de famílias advindas do sul nas aldeias daqueles nascidos no litoral, e que muitos casamentos, tensionamentos e outras ordens de relações conectavam essas populações, sem contudo homogeneizá-las.

Também nos estados do sul do Brasil, na Argentina e no Paraguai conexões entre essas chamadas parcialidades estavam sempre a reconfigurá-las em novos enredamentos. Como ocorria no sudeste, no entanto, casamentos daqueles reconhecidos como Mbya com brancos eram raros e controversos, enquanto entre os reconhecidos como Xiripa (Nhandeva) eram mais frequentes. Cadogan (1959b), por exemplo, destaca a frequência de intercasamentos dos Xiripa tanto com Mbya como com paraguaios não indígenas na primeira metade do século XX. Aos Xiripa, os Mbya costumam atribuir maior facilidade de misturar-se não apenas com jurua, mas também com outros indígenas, como os Kaingang e os Terena.

Muitos Mbya dizem que o casamento com Xiripa combina porque suas línguas são respectivamente compreensíveis, mas a conjugalidade com pessoas que falam outras línguas deve ser evitada pela incompatibilidade de suas almas. A língua não é concebida como um conjunto de convenções, e sim como afecção daqueles que habitam as pessoas na condição de suas almas, os nhe'é. Cadogan (1959) traduziu nhe'é como "alma-palavra" justamente pela língua indiciar a presença do nhe'ẽ no corpo do sujeito. Já Clastres (1990 [1974]) traduziu nhe'ẽ como "palavra-habitante".

As palavras circulam entre corpos de modo a fazê-los mutuamente humanos, ativando modos singulares de afetar e ser afetado. Muitos Guarani comentam a dificuldade de tradução de sua língua - ou impossibilidade, em algumas modalidades discursivas - por não se tratar de diferentes expressões de um mesmo mundo, e sim do acesso a diferentes mundos. Como enfatizado por Hélène Clastres (1978), a língua estabelece um nexo de continuidade entre os Guarani e suas divindades, sendo algumas modalidades discursivas na opy as próprias falas dos deuses. 
Diferentemente de outros viventes desta terra, os nhe'ẽ porã ("belo") que animam os corpos guarani provêm de um mesmo complexo de moradas celestes, para onde retornarão após a morte do sujeito. ${ }^{19}$ Tais moradas estão dispostas em várias alturas em relação à terra e em diferentes direções em relação ao trajeto do sol. ${ }^{20}$ Quando um guarani é gestado, o nhe'é é enviado para compor sua pessoa. Após um processo de aproximação e vinculação ao corpo, o nhe'ẽ revela sua proveniência ao enunciar seu nome ao karai, codificando sua filiação a um Nhanderu ("Nosso Pai") ou Nhandexy ("Nossa Mãe") associados a essas diferentes moradas. ${ }^{21}$

Retomando a afirmação de Tata'i de que o sangue guarani não aguenta a mistura com os brancos, tal afecção é indissociável do nhe'ẽ, que se sente desconfortável com o sangue jurua e prefere partir, deixando a pessoa suscetível a toda sorte de agenciamentos, incorrendo em transformações corporais. Por esta razão, uniões com brancos costumam ser reconhecidas como uma modalidade de-jepota. Tal expressão é composta pelo verbo "querer" (-pota), precedido por uma partícula com função reflexiva ou passiva (-je). Sugere assim um agenciamento em que o querer da pessoa é capturado pelo desejo de outro, que se apossou de sua subjetividade (Macedo 2013; Pierri 2013).

Uma tradução recorrente para-jepota entre meus interlocutores guarani é "se encantar". Quando um dono extra-humano (ija), geralmente animal, seduz e captura o corpo-afeto de alguém, ele ou ela passa a desidentificar-se com seus próprios parentes (Pissolato 2007; Mendes 2009; Heurich 2011; Macedo 2009, 2013; Ramo Y Affonso 2014 etc.). Há períodos de maior vulnerabilidade a essas afecções, como no nascimento de um filho, ou do engrossamento da voz entre rapazes púberes e da menarca nas moças. Como é comum nos mundos ameríndios, o sangue menstrual exerce uma particular atração em seres extra-humanos, parecendo-me significativo que uma interlocutora guarani de Tempass (2008: 297) tenha pronunciado "misturação" em vez de "menstruação", já que o corpo fica mais suscetível a toda sorte de misturas.

O corpo canibal, diz Tata'i, aguenta a mistura. Já os Guarani passam a aparentar-se com outros, muitas vezes assumindo uma posição de predador em relação aos parentes. Essa transformação, não raro, efetiva-se após a morte do sujeito, cuja vida definhou em razão desse agenciamento e cujo cadáver passa a assumir formas animais e a vingar-se dos vivos ou seduzi-los.

Em diferentes composições e gradações, porém, os corpos são inexoravelmente misturados, a questão sendo o manejo dessa mistura e seus efeitos transformacionais. Silveira (2011:164) destaca a expressão jopara referindo-se a diferentes modalidades de mistura ou variação, como palavras em português ou espanhol em falas guarani, o sêmen de diferentes homens no ventre de uma mulher, o milho com feijão, ou o casamento com brancos. 
Na Serra do Mar e no interior paulista, casamentos com brancos foram ficando cada vez mais frequentes entre os Tupi a partir da década de 1970. Mas a familiarização dos jurua na vida das aldeias nunca deixou de ser desafiante, de modo que Cherobim (1986) aponta uma grande instabilidade política no Bananal decorrente de conflitos entre "índios", "mestiços" e "brancos". ${ }^{22}$ A presença de igrejas protestantes e disputas territoriais eram temas centrais do conflito, que culminou com a morte do cacique e uma dispersão das famílias a partir dos anos 1980, quando formaram novas aldeias ou foram viver em outras existentes (Danaga 2016). Dois filhos e três filhas do líder assassinado foram para o Silveira, onde um irmão deles, Jejoko, já vivia desde a década anterior.

Tais irmãos casaram-se com Mbya, de modo que participam plenamente da rede de aldeias guarani no sul e sudeste do país. A despeito dos casamentos e dos filhos e netos nos quais se reconhece essa dupla descendência, em distintas conjunturas Tupi e Guarani não deixam de atualizar diferenças no Silveira, frequentemente mobilizadas em situações de conflito (Macedo 2009). A depender do contexto performativo e seus equacionamentos políticos, pessoas tupi guarani podem posicionar-se como Tupi ou Guarani, ativando capacidades vinculadas a uma ou à outra gente. ${ }^{23}$ Uma dessas pessoas é responsável pela opy e liderança de um dos núcleos da TI. Há alguns anos ele e seus xondaro e xondaria pintam-se e vestem-se cotidianamente com indumentária de sementes, fibras e penas. Tal liderança disse-me que essa ornamentação ativa a força dos antigos Tupinambá, e apenas os Tupi hoje têm disposição de incorporá-la, já que os Guarani só se pintam para apresentações culturais.

Entre os Tupi de outras aldeias que se formaram a partir do final da década de 1980, casamentos com não indígenas tornaram-se mais recorrentes, de modo que nas gerações seguintes muitos não falam a língua. Concomitantemente, casamentos com Mbya foram ficando cada vez mais raros nessas famílias com afins jurua. Os argumentos mobilizados pelos Mbya não costumam ser culturalistas (a perda da língua como "aculturação"), tampouco restritos a estratégias políticas diante dos brancos ou entre famílias, e sim afectivos. O gradiente de mistura nos corpos tupi compromete a socialidade pautada pelos nhe'ẽ porã, os quais não se acostumam e afastam-se. Trata-se, portanto, de uma cosmopolítica cujos agenciamentos ocorrem dentro e fora dos corpos, incluindo adoecimentos e adversidades que extrapolam o domínio humano.

A despeito de suas singularidades, etnografias recentes em aldeias de maioria tupi - como de Almeida (2016) em Ywy Pyhaú (Barão de Antonina/ SP, próximo a Araribá), Mainardi (2014) na TI Piaçaguera (Peruíbe/SP) e 
Danaga (2016) na Ywyty Guaçu/Renascer (Ubatuba/SP) - trazem à cena aspectos comuns na vida nessas aldeias, como o alto índice de casamentos com não indígenas, domínio da língua entre os mais velhos e redes mais localizadas do que nas aldeias mbya, associadas a uma menor mobilidade. Tais trabalhos mencionam uma intensa interação de famílias nessas aldeias com a população do entorno para atividades de lazer, trabalho, religião, festas, comensalidade, conjugalidade e apoios mútuos (Brusco 2016).

Podemos supor assim que há hoje uma circulação mais restrita entre a maioria daqueles que se reconhece como Tupi, ao passo que há uma mistura mais intensa. A condição de misturados é algo enfatizado pelos Tupi segundo essas etnografias, mas não de mestiços. Estes são identificados como os que apenas possuem ascendência, contudo não vivem como indígenas. A vida na aldeia faz dos Tupi Guarani puros-misturados (Almeida 2016:140) pelo que implica nos afetos dos corpos, incluindo modos de comer, adoecer e cuidar, sonhar, cantar, dançar, rezar, fazer crescer filhos, plantas, bichos e objetos.

Como destaca Mainardi (2014), há afins jurua que incorporam modos de relacionar-se e viver da coletividade, mas a familiarização dos brancos é um desafio sempre presente na feitura da vida na aldeia, por vezes incorrendo em conflitos e cisões. Há aldeias tupi em que a proibição de casamentos com brancos já foi uma regra, mas mostrou-se de difícil efetivação, em parte pela recusa dos Mbya em se casarem com aqueles que não falam a língua. A circulação dos Mbya foi assim diminuindo nas aldeias de maioria tupi, ao passo que se intensificou na rede crescente de aldeias de maioria mbya no sul e sudeste do país.

\section{Circular em modulações guarani}

Os Guarani não param. Esta é uma afirmação que se ouve muito nas aldeias mbya e constitui um tema extensamente abordado na etnologia. Desde migrações motivadas pela orientação das divindades - em trabalhos clássicos como de Nimuendaju (1987 [1914]), Cadogan (1959), Pierre Clastres (1990 [1974], 2003 [1974]) e Hélène Clastres (1978) -, também suscitadas por conflitos territoriais, até a mobilidade no complexo de aldeias dispersas no território que compreende o Paraguai, a região argentina de Misiones e os estados do sul e sudeste do Brasil - em que os trabalhos de Garlet (1997) e Ladeira (2007) são referências fundamentais.

A seu turno, Pissolato (2007) apontou a multiplicidade de escalas em que essa mobilidade se efetiva, por meio de um sistema multilocal em que não apenas famílias circulam pelas aldeias, mas também pessoas circulam entre 
famílias, que experimentam constantes rearranjos. Boa parte dos Guarani-Mbya casa-se algumas vezes ao longo da vida, sendo os filhos dessas uniões distribuídos de diferentes maneiras quando ocorre a separação. Assim, é comum pessoas terem filhos em várias aldeias, bem como avós, irmãos, tios e primos, compondo uma rede tão mais densa quanto mais esgarçada. Para cada guarani-mbya costuma haver alguém reconhecido como parente ou como alguém com quem se pode aparentar na maioria das aldeias dessa rede que se adensa nas regiões Sul e Sudeste.

Além dessa engrenagem de afastamentos e aproximações em constante rearranjo, Ramo Y Affonso (2014) chama a atenção para a produção ritual e cotidiana de diferenças de modo a ensejar movimento e troca, a partir de idiomas de gênero, ciclo de vida, liderança-e-assistência etc. Também correlacionando circulação, transformação e trocas, Ladeira (2007) e Testa (2014) abordam múltiplos caminhos de pessoas e saberes nos corpos, nas aldeias, no leito terrestre e nos patamares celestes. Por sua vez, Santos (2016) enfatiza a esquiva como movimento-chave na socialidade guarani - na dança xondaro, no comportamento de tricksters e outros personagens de suas histórias, nas articulações de lideranças em meio a famílias e coletivos maiores, assim como em incorporações como mote para diferenciações nas relações com os brancos ao longo da história e de conjunturas atuais.

No âmbito das famílias, Pissolato (2007) ainda destaca a alteridade do casal como engrenagem diferenciante. A consanguinização dos afins pela corresidência, comum nas terras baixas sul-americanas, ${ }^{24}$ é matizada entre os Mbya em função de os cônjuges não serem geralmente incluídos na classificação -etarã, "parentes". A conjugalidade produz pessoas, mas também diferenças que constituem as pessoas. Ciúme desmedido, melancolia e adoecimentos figuram entre motivos para separações, sendo muitas vezes associados à feitiçaria (mba'evyky) do cônjuge ou de seus parentes.

Há, portanto, o engajamento na produção de filhos entre os cônjuges, bem como a implicação mútua dos corpos entre aqueles que vivem juntos, compartilhando substâncias, cuidados e experiências, mas partir para outros lugares e relações está sempre no horizonte de possibilidades. E esta é também uma disposição interna à composição das pessoas. Como mencionado, o nhe'ẽ porã que habita a pessoa na condição de sua alma (ou uma delas) provém de diferentes moradas celestes. Ao vincular-se a um corpo, o nhe'ẽ confere-lhe capacidades de linguagem, cognição e agência. Mas é preciso que ele se acostume, demandando investimentos constantes na vida cotidiana e cerimonial das pessoas. ${ }^{25}$ A começar pela atribuição de seu nome, que indica a proveniência do nhe'é na cartografia celeste, composta de moradas em diferentes direções. Se não for chamado por seu nome correto, 
o nhe'é sente-se fora de lugar, não se acostuma e tende a partir, adoecendo a pessoa e deixando-a perdida, sem saber quem é.

Assim como nhe'é deve acostumar-se no corpo que habita, o mesmo se passa com a pessoa em seu arranjo familiar, e com as famílias nos lugares em que vivem. A palavra guarani com que meus interlocutores traduzem "acostumar" é - vy'a, que é também "alegrar". Tal expressão mbya parece-me ressoar no conceito de Spinoza (2013 ([1677]) de alegria, como um afeto que resulta de uma composição de corpos que aumenta a potência de agir de um deles ou de ambos. ${ }^{26}$ Se essa mistura incorrer num afeto triste, que faz definhar, a circulação efetiva-se como busca de outras composições.

Nas aldeias das regiões Sul e Sudeste do país, tal circulação acontece num território esquadrinhado por rodovias, ferrovias, fazendas, cidades, parques e outras delimitações físicas e/ou jurídicas impostas pelo kuaxia reko, expressão que os Guarani costumam associar aos dispositivos burocrático-administrativos do Estado e da sociedade civil [kuaxia: papel e seus derivados; -eko: modo de viver que expressa relações/afecções que compõem as gentes].

A despeito da proximidade, e por vezes da contiguidade com centros urbanos, não são muitos os Mbya que conheço que se dispuseram a viver fora das aldeias, sobretudo de modo permanente. Mas também são poucos os que não fazem incursões frequentes às cidades para atividades como compra de produtos, venda de artesanato, palestras e apresentações culturais, trabalhos temporários, jogos de futebol, bares, participação em festas e eventos com suas bandas de forró ou de rap, entre outras.

A internet aumenta exponencialmente essas conexões, tanto entre as pessoas nas aldeias - com destaque para o uso intenso do Facebook, sobretudo entre os mais jovens que se comunicam com pessoas em diferentes estados - como também com pessoas não indígenas ou de outros povos, intensificando a circulação de notícias, músicas, filmes, tecnologias, editais de projetos, eventos, mobilizações políticas, amizades, paixões, conflitos etc.

A crescente proximidade física e conectividade com as cidades, contudo, é concomitante a uma incisiva descontinuidade com os brancos no parentesco. Na maioria das aldeias mbya, como destacado, casamentos e geração de filhos com jurua via de regra são interditos ou controversos pelas consequências que podem trazer aos corpos da pessoa ou daqueles próximos a ela. Quando uma união acontece - e elas nunca deixam de acontecer - é frequente que lhe seja atribuída a causa de alguma adversidade subsequente, como a morte ou o adoecimento de alguém.

As explicações que costumo ouvir para essa proibição é que um corpo não combina com o outro, enfraquecendo um deles ao aparentarem-se. 
Como mencionado por Tata'i, dizem que o sangue guarani é mais puro, por isso mais suscetível de enfraquecer-se com a mistura ao sangue jurua. Nessa direção, ouvi em uma aldeia na capital e em outra no Vale do Ribeira que Jesus Cristo é filho de Tupã com uma princesa branca que vivia em um castelo, e que ele sangrou tanto antes de morrer porque teve que tirar todo o sangue jurua para então alcançar a imortalidade.

A mistura não implica assim homogeneização entre os sangues, ou entre o que quer que seja, tampouco estabilização da composição resultante, e sim movimento e diferença. Algo análogo passa-se com o nhe'é, que deixa de alegrar-se, acostumar-se, compor-se com aquele corpo que está aparentando-se com jurua, preferindo afastar-se. Alguns Guarani também reconhecem adversidades posteriores ao casamento com jurua como tekoa'á, que traduzem como "provação" de Nhanderu, no sentido de algo que uma divindade faz para desestabilizar a pessoa e assim motivar sua busca por fortalecimento.

A referência a substâncias ou componentes da pessoa, como sangue

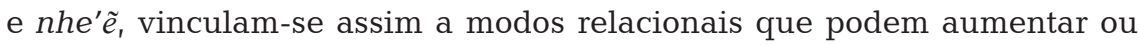
diminuir a potência de existir. Uma regra recorrente é que aquele que se casa com jurua deve viver fora da aldeia. Pissolato (2007) destaca como uma dimensão importante desse afastamento o corte na rede de trocas ensejada pela socialidade multilocal, que pode incidir no distanciamento do nhe'é.

Há, contudo, aqueles que não deixam as aldeias e ali criam seus filhos com o cônjuge jurua. Essas crianças, mesmo que o pai ou a mãe sejam jurua, podem ter um corpo com afecções guarani, caso cresçam comendo com e como nhandekuery, frequentando a casa de reza, recebendo tataxina rekoaxy (a fumaça dos cachimbos) e, sobretudo, sendo capazes de falar a língua, que expressa a presença de nhe'ẽ porã. Contudo, muitos costumam considerar maior a possibilidade de essas pessoas virem a se aparentar com outros, como jurua ou outras gentes.

Nas poucas aldeias mbya da região Sudeste em que há alto índice de casamentos com brancos, costuma haver o empenho na familiarização dos corresidentes e vizinhos, em detrimento de arranjos familiares dispersos na rede de aldeias, restringindo inclusive sua circulação nela, numa dinâmica que pode ser aproximada à das aldeias tupi. Em sua etnografia em Mbo'yty (Maricá/RJ), Pereira (2014) destaca o investimento na guaranização dos jurua afins e nos aliados, como ele próprio na condição de antropólogo. Em contrapartida, aponta a ambiguidade da condição dos Mbya cujos afins são jurua na rede de aldeias, multiplicando-se suspeitas de que seriam feiticeiros (ipajeva'e). 
Já aqueles que descendem de uma união com jurua e que não falam guarani, mesmo que tenham um pai ou mãe guarani e que vivam em uma aldeia guarani, muitas vezes são chamados de jurua, ou então de jekupe. Alguns guarani apresentaram-me Jekupe como dono de uma das moradas celestes mais próximas da Terra e que em tempos primordiais ele conseguira imortalidade mesmo tendo se casado com uma branca. Por isso os que nascem de um casamento com jurua podem ter seu nhe'é afiliado à sua morada ou recorrer a ele nas rezas.

Entre aqueles que não aguentam a mistura, contudo, a afinidade potencial $^{27}$ dos jurua e de outros com os quais não se deve aparentar é condição para que as trocas com eles estejam sempre ensejando diferenças. Incorrer na conjugalidade poderia ser justamente deixar de diferir, que associam ao definhamento, confinamento e apartamento do nhe'ẽ porã.

\section{Tekoaxy: adoecer de outros, fortalecer com outros}

Alguns guarani comentam que antes aqueles que casavam com brancos não duravam nem um mês. Antigamente também existia muito mais -jepota com animais e outros seres, pois os Guarani "se encantavam com qualquer coisa", como expressa Karai Tataendy, no Silveira. Mas nunca como hoje se teve tanto nhe'é mba'eaxy ("coisa-sofrimento", "o que é sofrimento", "doença"), que costumam traduzir como doença espiritual, em que o nhe'é afasta-se e a pessoa fica mais suscetível a toda sorte de agentes etiológicos, cujos sintomas podem ser melancolia, apatia, agressividade extrema, raiva desmedida, não saber quem é ou não conseguir levantar-se. O aumento do consumo da comida jurua é uma das causas principais aventadas por meus interlocutores guarani. Por seu excesso de sal, açúcar, óleo e condimentos, a comida jurua deixa o corpo mais pesado - não pelo eventual acúmulo de adiposidade, e sim porque o nhe'é sente-se confinado e não se acostuma (Macedo 2013).

Ainda que comam cada vez mais a comida dos jurua, os Guarani enfatizam que não comem como os jurua, tampouco com os jurua. Em aldeias próximas ou inseridas em centros urbanos, a comensalidade é um dos modos fundamentais de produção-atualização das afecções que singularizam nhandekuery. Certa vez visitei Tupã Mirĩ no Jaraguá (na capital paulista) no meio da tarde, quando comia na área comum em que ele e seus parentes de casas vizinhas costumam alimentar-se juntos. Comentei que estavam almoçando tarde e ele me disse que quem tem hora para comer é empresário e empregado. Estas são posições fortemente associadas ao jurua reko, 
o modo de viver ou a disposição afectiva dos brancos. Ao menos nas aldeias no estado de São Paulo, são poucos os Guarani-Mbya que se submetem a um regime de trabalho assalariado fora das aldeias. As principais fontes de renda costumam ser aposentadorias, programas de transferência (como o Bolsa-Família) e empregos dentro das aldeias, sobretudo nas áreas de saúde e educação.

Os trabalhos na cidade frequentemente são no comércio de artesanato e outros produtos da aldeia nas ruas, ou então apresentações e palestras, e ainda ocupações temporárias em atividades variadas. Mas empregos fixos com carga horária definida são raros. O seguinte comentário de Karai Tataendy aborda esta questão em ressonância com aquele de Tata'i, ao contrastar disposições canibais às indisposições dos Guarani à mistura com os brancos:

No começo do mundo a gente tinha simplicidade, não atacava, não fazia nada, nada. Só plantava, comia caça, não atacava ninguém. Agora os outros índios atacavam a tribo guarani, matavam, comiam os próprios parentes. Matava, assava, ou comia cru mesmo. [...] Esses índios têm contato de menos de 100 anos, a gente teve contato com branco em 1.500, e esses índios agora [...] são mais avançados no meio dos brancos. Hoje eles têm médico índio, dentista índio. Nós Guarani somos um povo que não é pra se misturar realmente com branco. Por isso a gente hoje sente dificuldade, é uma realidade diferente dos índios de Amazônia. [...] Eu mesmo penso "puxa, quero ir trabalhar", mas você vai pra cidade e não se acostuma a ficar lá, então já volta. O Guarani não é um povo que enfrenta a vida do branco normalmente.

Esse "não se acostumar" foi traduzido na língua como ndovy'ai, ${ }^{28}$ que corresponde à forma negativa de -vy'a, "alegrar". A proximidade dos brancos, aos quais também chamam de hetava'ekuery ("os que são muitos"), impõe cotidianamente a condição minoritária como eixo existencial entre os Guarani. Inversamente ao ideal eugênico da raça pura, em que a mistura com os mais fracos é sinal de degeneração, os Mbya costumam dizer que justamente por serem mais fracos não aguentam a mistura. É uma questão de resistência para a coexistência de diferentes e não de imposição de um único padrão de existência.

Serem poucos é algo sempre enunciado pelos Mbya quando falam de sua condição. Como formulado por Karai Papa Mirĩ, quando morava no Silveira:

desde o começo fomos preparados para não ser muitos. Enquanto estamos colhendo uns três, quatro, cinco milhos aqui, do lado dos hetava'ekuery estão colhendo milhares. (...) Então por isso aí existe tanta violência, morrem tantas pessoas, e mesmo assim vocês continuam aumentando. 
Como viventes nesta terra que concebem minada pela perecibilidade, os Guarani reconhecem seus corpos como tekoaxy, expressão composta que vincula "viver" (teko) e "sofrer" (axy) ${ }^{29}$ Pierri (2013) aborda densamente a condição perecível (marã) desta terra e seus seres tekoaxy, em contraste com a imperecibilidade (marãe'ỹ) dos mundos celestes. O autor destaca como materiais e tecnologias associadas à durabilidade, como pedras, metais e produtos como carros, aviões e computadores, têm existência prototípica nessas moradas dos imortais, sendo anteriores e mais potentes do que as versões rekoaxy aqui dominadas pelos jurua.

Assim, o que existe nesta terra são imagens perecíveis de modelos originários imperecíveis dos mundos celestes. -Ekoaxy seria um modo de adjetivar tal perecibilidade, enquanto tekoaxy remeteria à condição dos seres perecíveis. Ainda com Pierri, a busca de imitação das divindades pelos Guarani constituiria uma engrenagem transformacional de corpos e relações, no que reconhece um platonismo em perpétuo desequilíbrio (2013:99ss). Diferentemente do modelo estático de Platão, que contrasta formas prototípicas inteligíveis (ideias) e suas imagens sensíveis como cópias imperfeitas, entre os Guarani as categorias sensíveis do perecível e imperecível constituiriam o nexo diferenciante dos mundos terrestre e celeste.

A depender do contexto enunciativo, tekoaxy costuma ser traduzido por imperfeito por muitos Guarani. Na literatura, esta também é a tradução mais comum desde a obra de Cadogan. Ao vincular tekoaxy à perecibilidade, Pierri aponta a inadequação de tal tradução, justamente por sua matriz platônica, que desconsidera as propriedades sensíveis mobilizadas no pensamento guarani (2013:164). Se tomarmos imperfeição como um conceito guarani, contudo, penso que ele deva ser aproximado não ao de Platão, mas novamente ao de Spinoza, remetendo à vulnerabilidade às afecções, e não ao contraste com um modelo estático e transcendental de perfeição.

De acordo com a proposição spinozista (2013), o modo com que experenciamos o mundo advém dos efeitos que sofremos de outros, que nos habitam e/ou atravessam. ${ }^{30}$ Mas o desafio da existência não é a natureza composta dos seres, e sim a maior ou menor vulnerabilidade a ações que possam diminuir sua potência de agir, decompondo essas relações que os constituem. Quanto maior a potência de compor-se com outros, maior seu grau de perfeição. O argumento central da Primeira Parte da Ética de Spinoza é que o grau máximo de perfeição constitui o corpo composto de todos os corpos, que é o corpo de Deus. Por ser a multiplicidade em sua máxima potência, quaisquer alteridades lhe são imanentes, destituindo-o de qualquer vulnerabilidade. 
No cosmos guarani, por sua vez, talvez não exista um corpo desprovido de antagonistas. Mesmo as divindades oscilam sua potência, enfraquecendo no ara yma ("tempo velho", próximo ao outono e ao inverno) e fortalecendo no ara pyau ("tempo novo" próximo à primavera e ao verão). Pelo que me ensinaram alguns guarani, contudo, tal oscilação incorre num maior recolhimento ou expansão relacional/agentiva, e não em decomposição, como entre os mortais no leito terrestre.

O mesmo se passa com os nhe'ẽ porã nos corpos guarani. Muitos me disseram que adoecimentos ou -jepota ocorrem pelo afastamento do nhe'é porã, mas que este jamais é capturado. Nessa direção, interlocutores de Santos (2016) mencionaram a copresença de um nhe'é porã e um nhe'é rekoaxy na composição da pessoa. Enquanto o nhe'ẽ rekoaxy experimenta sofrimentos e outras afecções nesta terra, o nhe'ẽ porã é insuscetível aos agenciamentos dos seres -ekoaxy.

Seja como for, a própria existência dos nhe'é pressupõe um corpo composto/efetuado por outros. E este me parece ser o cerne da condição tekoaxy, convergindo viver (teko) e sofrer (axy) efeitos de outros. Há assim tanto o nexo com as divindades, em que a perecibilidade constitui uma engrenagem transformacional (Pierri 2013), como todas as demais relações que se experimenta nessa terra, incorrendo em fortalecimento ou definhamento dos corpos, ou mesmo em sua decomposição. Podemos assim estender a condição perecível dos seres tekoaxy à sua vulnerabilidade aos agenciamentos de toda sorte.

Algumas falas recorrentes nas opy são significativas desta condição, tais como: Ãgue kuery ha'e ramigua nhande mboriau ("Os espíritos dos mortos nos deixam fracos"); Opamba'e nhande yvy rupare, opamba'e petei guigua regua e'ỹ ma ("Estamos suscetíveis a todas as coisas que acontecem na superfície da terra"); Yvy regua kuery nhandere onhea'ã ("Espíritos desta terra estão nos ameaçando"); Yvy rupare nhanhombarete uka porã ãgua rami e'ỹ te ̃ mamo mamo tataipy rupa javi rupi ("Nesta terra muitos tentam acabar com nossa força em todas as aldeias").

As afecções, efeitos das misturas, não são contudo necessariamente más. ${ }^{31}$ A vida nesta terra é também composta de bons encontros, fortalecendo corpos e relações. Além dos vínculos com os Nhanderu e Nhandexy, bem como entre nhandekuery, os bons encontros podem incluir a afinidade potencial com outros, já que a incorporação de potências animais, de plantas e outros seres, inclusive dos brancos, é fundamental para a vida nesta terra, investindo os corpos de capacidades e podendo aumentar sua força de existir.

Assim como entre outros ameríndios, a posição de sujeito entre os Guarani implica habitar um mundo onde se é constantemente povoado e alterado por outros, em que sucumbir à predação pode incorrer na perda 
da humanidade compartilhada com os parentes. Mas podemos reconhecer modulações singulares da chamada predação ontológica entre os Guarani em relação a socialidades amazônicas. Os enunciados de Tata'i e Karai Tataendy supracitados são exemplos de elaborações dessa diferença, no contraste que estabelecem com disposições canibais, em ambas as ocasiões vinculando-as a uma facilidade de mistura com os brancos - casar com eles, no contraste de Tata'i entre Guarani e Tupi; trabalhar com/como eles, no contraste de Karai Tataendy entre Guarani e povos amazônicos.

Obras de referência na etnologia também reconheceram um anticanibalismo guarani, em que vetores do devir-outro se voltam para a divindade em detrimento da animalidade ( $\mathrm{H}$. Clastres 1978, P. Clastres 1990; Viveiros de Castro 1986). Fausto (2005) vai adiante, afirmando que o contato com missionários e a experiência colonial conduziram a uma crescente negação da predação ontológica como fundamento do poder xamânico e da reprodução social entre os Guarani, processo que designou como desjaguarificação.

Desconstruindo tal hipótese, Pierri (2013) detalha como o xamanismo mbya articula os eixos vertical e horizontal em agenciamentos envolvendo os Nhanderu e Nhandexy nas moradas celestes e os ija nos domínios terrestres. O autor ainda aponta não ser apenas a predação que está em jogo na captura de subjetividades entre os Guarani, mas também a compaixão, pela identificação excessiva com o outro e seus perigos transformacionais. Ambas as disposições são destacadas por Viveiros de Castro e Taylor (2006) por sua centralidade nas socialidades ameríndias, integrando o mesmo sistema pautado pela predação ontológica.

Entre os Guarani, o manejo das incorporações não prescinde de capturas, $^{32}$ mas há também a busca em não se fixar na posição de predador, de modo a predominar a forma relacional da dádiva. Assim, deve-se pedir aos ija ao armar mundéus, extrair plantas, andar na mata ou próximo a rios, entre outras ocasiões. Mas o limiar entre dádiva e roubo está sempre em movimento, incorrendo numa diplomacia tensa com os donos, por vezes vertida em adoecimento, -jepota ou outras retaliações. Daí a importância de efetivar a desconexão com os ija, por exemplo, jogando fumaça do cachimbo na caça ou em outros alimentos e coisas a serem apropriadas/incorporadas.

A fumaça dos cachimbos é também um dispositivo de conexão com os Nhanderu e Nhandexy e entre pessoas nas aldeias dispersas num vasto território por onde circulam conhecimentos, capacidades e afetos. Entre estes parentes e afins, contudo, suspeitas de agressão xamânica e outras ordens de conflito também estão sempre a transmutar dádivas e roubos. Como modulação guarani da predação ontológica, a condição tekoaxy promove assim uma incessante oscilação na potência de existir, inscrevendo nos corpos 
um movimento constante de adoecimento (-mba'eaxy) ou enfraquecimento (-mokangy) e fortalecimento (-mbaraete), palavras sempre presentes na vida das aldeias e nas falas cerimoniais, que remetem aos efeitos de relações.

De maneira mais pungente do que na experiência de outros povos que vivem mais afastados das cidades, entre os Guarani as relações com os jurua costumam incidir no polo do adoecimento, assim como os encontros na casa de reza remetem ao polo do fortalecimento (Macedo 2013). Mas isso não significa que haja menor busca de relações com os brancos, e sim que elas são motivantes de uma maior busca de conexão com nhandekuery e Nhanderu e Nhandexy kuery na opy. Fortalece-se com outros porque se adoece de outros.

De acordo com etnografias junto aos Wari' (Vilaça 2007), Karajá de Buridina (Nunes 2013), Yanomami e outros povos indígenas (Kelly 2016), relações com os brancos podem mobilizar uma duplicidade do corpo característica da transformabilidade xamânica. Num movimento análogo à genderização do divíduo melanésio tal como descrito por Strathern (2006), a depender da configuração relacional, o sujeito acionaria uma posição, portanto um corpo, de branco ou indígena. No caso dos Karajá de Buridina, não há restrições ao casamento com brancos, já que a mistura do sangue não incorre em sua indiferenciação, e sim numa relação de diferença interna à pessoa, engendrando o que Nunes (2013) reconheceu como socialidades alternativas.

Este parece ser o caso dos Tupi Guarani com quem convivi no Silveira, em que posições de Tupi ou de Guarani podem ser mobilizadas alternativamente, a depender de configurações políticas, ou outras relações e capacidades a serem ativadas. Mas nas relações entre os Guarani e os jurua parece-me que essa experiência é vivida de modo mais dilacerante, havendo uma maior ênfase no desequilíbrio implicado na duplicidade dessas posições, de modo que o fortalecimento de uma posição incorre no enfraquecimento da outra, e não apenas em seu eclipsamento. Aproximar os brancos afasta o

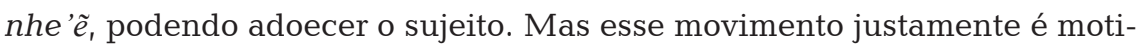
vante (Wagner 2010) do fortalecimento buscado na opy.

Certa vez, Karai Tataendy entoou-me um canto dizendo que o achava o mais bonito: "Mamo tetã gui reju? (2x)/ Tetã ovy rajy'i (3x)/ Eikere xevy, eikere devy $(2 \mathrm{x})$ ". Numa tradução aproximada, a letra diria o seguinte: "De qual morada-cidade você vem?/ Filha da morada-cidade azul/ Entre por você, entre por nós". Ele me disse que era sobre uma moça que deixara sua aldeia para morar na cidade, mas não tinha se acostumado, e o canto é o momento em que ela está sendo recebida de volta na opy. Em outra ocasião, comentei sobre este canto com Tata'i, e ela discordou que falasse de alguém que tivesse necessariamente saído da aldeia, e sim de uma moça que não 
sabe mais quem ela é, de qual morada celeste vem seu nhe'ẽe por isso os parentes a estavam chamando para a casa de reza. Tenha a moça deixado a aldeia, ou o nhe'é deixado o corpo da moça, ambas as leituras do canto remetem a esse movimento de afastamento e volta, de adoecimento e busca de fortalecimento que os Guarani experimentam intensamente em várias dimensões relacionais.

Num mundo em que os jurua estão por toda parte, contudo, a constituição dessa humanidade compartilhada, nhandekuery, prescinde de contiguidade espacial. Daí a reiterada conexão com as aldeias celestes em rituais diários e entre pessoas dispersas em aldeias que podem estar muito distantes. Modalidades de sopro como palavras, fumaça de tabaco e cantos-rezas figuram como importantes caminhos nos eixos vertical e horizontal dessa cartografia mbya de vínculos entre distantes.

Já em relação aos jurua que vivem próximos, a evitação (jamais absoluta) de conjugalidade vem configurando um modo de estabelecer conexões parciais, circulando nas redes sem ser enredado. Trocas comerciais, parcerias em projetos, eventos e intercâmbios cada vez mais frequentes entre os Guarani e os jurua figuram assim como modalidades de aliança em que se produzem perspectivas pelas quais pessoas/gentes posicionam-se em relação a outras, diferenciando-se de forma a conferir à predação um lugar residual.

Contudo, assim como nas interações com os ija, a questão é que a doença está sempre a turvar tais alianças, expondo o dom como um roubo de alma (Viveiros de Castro 2007:121). No que concerne à aliança nos mundos ameríndios, Viveiros de Castro destaca que a dimensão intensiva da troca não deixa efetivar a descontinuidade, de modo que as coisas agem umas sobre as outras em razão de sua diferença de potencial.

Em uma fala de aconselhamento (-mongeta), um karai de uma aldeia na capital paulista usou a expressão jurua rekoaxy ao mencionar o desespero ou a apatia frequente dos jovens nas aldeias hoje em dia quando perdem ou quebram o celular, ou quando não têm dinheiro para gastar no final de semana. Sua fala era entremeada pela imitação desses jovens, provocando risos e expressões de concordância que são comuns na opy: anhete ko! ("Isso é verdade!"). A expressão jurua rekoaxy foi-me traduzida na ocasião como "doença jurua", o que compreendi como uma vinculação da doença (mba'eaxy), como sintoma da ação de outro(s), à vulnerabilidade aos efeitos (-ekoaxy) desses objetos adquiridos dos brancos - que, por sua vez, são versões rekoaxy, perecíveis, dos objetos nas aldeias celestes (Pierri 2013).

A doença ali remeteria a um descontrole nas incorporações, deixando-se acostumar, de modo a não mais prescindir do dinheiro ou do celular. Nessa etiologia guarani, contudo, indisposições dos corpos operam também como 
força diferenciante entre aqueles que vivem nas cidades ou próximo a elas, como não se acostumar com um emprego fixo fora da aldeia; ou mudar de aldeia e não se submeter às prerrogativas de frequência escolar dos filhos no Programa Bolsa Família; ou mudar de nome (o que é recorrente em casos de doença) e dificultar o monitoramento de dados pelo Subsistema de Atenção à Saúde Indígena; ou sentir-se indisposto e não cumprir o cronograma de atividades acordado em um projeto. De inúmeras maneiras, indisposições vinculadas ao adoecer ou ao não se acostumar vêm fazendo com que alianças estejam sempre atualizando diferenças. Em chave clastriana: a doença contra o Um, em que o não se acostumar implica um não se sujeitar.

\section{Misturas sem fim}

Como nota conclusiva, cabe reiterar que em elaborações guarani sobre suas diferenças em relação aos Tupi que vivem próximos (ou dentro de pessoas e coletivos), a povos amazônicos e aos brancos estão em jogo modulações de misturas, ou de potências, na composição das gentes. No que chamei de uma etiologia das disposições e indisposições dos corpos, circular pode ser um modo de fazer frente à mistura, pois ela está sempre acontecendo, de modo a reagir a efeitos de adoecimento, definhamento, confinamento, apartamento do nhe'ẽ. Por sua vez, disposições canibais fazem da mistura uma frente, manejando a circulação de modo a incorporar pessoas e capacidades.

Seja como for, a predação está em cena como estética relacional em que a posição de sujeito é desafiada pela instabilidade das posições de predador, presa ou ser domesticado/acostumado. Nos mundos ameríndios, tal desafio costuma ser enfrentado pela busca de manter-se no polo ativo da predação, de modo a evitar a posição de presa. Mas entre os Mbya a busca parece ser de não se fixar em nenhuma dessas posições, diferenciando-se de uma e outra sempre de modo incompleto. Em direção próxima, Pereira (2014) reconheceu entre os Mbya a posição de presas impresáveis. A seu turno, como mencionado, Santos (2016) destaca a esquiva do xondaro como movimento matricial na socialidade mbya, cuja arma é desarmar o outro, desestabilizando-o ao fazê-lo errar, no duplo sentido de deslocamento e engano.

Este texto buscou destacar como a doença, ou o não se acostumar, também remete ao manejo da vulnerabilidade. Em vez de fraqueza, a doença pode ser vista como extrema força de um povo que vive em meio aos jurua e outros sem se acostumar. De modo comparável aos desafios de destreza do xondaro ruvixa (líder) aos seus guerreiros, as doenças muitas vezes são percebidas como tekoa'ã, provações. É preciso dançar para enfrentar, estar 
em movimento para não se deixar definhar, capturar, domesticar, aparentar... numa oscilante linha melódica da existência entre lugares, pessoas, famílias e posições.

Seja como for, a diferença não é tomada como algo a ser superado ou separado. Entre os Tupi Guarani no estado de São Paulo a mistura não corresponde à fusão ou à homogeneização, tampouco circular entre os Mbya corresponde à depuração de diferenças. Circular e misturar são ênfases distintas de um mesmo movimento de diferir, indo ao encontro do que vem sendo formulado como contramestiçagens ou antimestiçagens no debate antropológico contemporâneo.

Na proposição de Kelly (2016), antimestiçagens remetem a conceituações indígenas sobre a diferença e suas extensões criativas nas relações com o Estado e os brancos a partir de uma lógica transformacional, cujo exemplo etnográfico é o que os Yanomami experimentam como um virar-branco. Em vez de tipos específicos de pessoas, yanomami e napë/branco são tomados como socialidades ou contextos performativos que podem ser acessados. Em chave wagneriana, Kelly volta-se para equivocações em jogo nessas relações, dadas as premissas multiculturalistas e identitárias dos brancos, que opõem tradição e transformação, ou convergem mestiçagem e homogeneização. Já Goldman (2015) faz uma inflexão clastriana ao propor a expressão contramestiçagens para pensar conexões que prescindam do protagonismo/antagonismo dos brancos e seus efeitos sobrecodificantes, a exemplo de relações afroindígenas no continente americano. Aqui, elaborações guarani sobre diferenças que os conectam a outros povos indígenas, aos não indígenas e a outros seres estão na interseção dessas propostas.

O texto buscou assim pensar diferenças não de modo culturalista, tampouco como estratégica política restrita ao domínio humano, mas numa chave intensiva, como parecem vivê-las aqueles para os quais Guarani, Tupi Guarani, jurua e outros são potências diferenciais que um corpo pode ou não experimentar, definhando ou fortalecendo-se, mas sempre se alterando.

Guarani-Mbya e Tupi Guarani são expressões compostas, mas cujas composições vinculam-se a diferentes imaginações conceituais. Guarani-Mbya é uma expressão que durante muito tempo foi mais usada pela antropologia do que pela população que ela buscava classificar. Operando uma depuração tipológica, Mbya corresponderia a um tipo específico da categoria englobante Guarani. Já Tupi Guarani é uma expressão que por muito tempo foi recusada ou ignorada pela antropologia para classificar a população em São Paulo que se identifica com ela, remetendo a uma composição de diferentes sem que haja depuração da diferença. 
Há brancos que questionam a existência de um povo Tupi Guarani, alegando ser este o nome de uma família linguística. Por haver alguns com a pele muito clara ou muito escura, há brancos que também questionam serem eles indígenas. Por isso os Tupi Guarani vêm fazendo repercutir a história de seu nome e a teoria da diferença que ela traz consigo, em que a mistura não se confunde com mestiçagem, já que não existe um todo sincrético que dela resulte.

Os jurua estão excluídos da composição do nome Tupi Guarani, mas podem participar da composição dos corpos. Talvez essa exclusão do nome seja para que ele não seja substituído por palavras não compostas, como "caboclos", "mestiços" ou "aculturados", entre outras de nosso leque classificatório homogeneizante. Ou para que os jurua não sobredeterminem o que pode um corpo na vida da aldeia.

Seja como afins potenciais - entre os Mbya - ou efetivos - entre os Tupi Guarani - os jurua figuram como uns entre muitos outros (humanos e extra-humanos, visíveis e invisíveis) no mundéu de um mundo pautado pela predação, em que corpos são incorporações, máquinas de mistura e circulação, de vingança e de dança.

Recebido em 30 de março de 2017

Aprovado em 04 de setembro de 2017

Valéria Macedo é professora no Departamento de Ciências Sociais e no Programa de Pós-graduação em Ciências Sociais (PPGCS) da Universidade Federal de São Paulo (Unifesp), São Paulo/SP, Brasil. E-mail: <vvaall72@gmail.com> 


\section{Notas}

* A escrita deste texto inicia com minha participação no Seminário Temático "Antropologias afroindígenas: contradiscursos e contramestiçagens" , coordenado por Márcio Goldman e Renato Sztutman na 40ª Anpocs, em 2016. Pude adensar questões ali trabalhadas em uma apresentação em maio de 2017 no CPEI (Centro de Pesquisa em Etnologia Indígena) da Unicamp, a convite de Artionka Capiberibe. Agradeço aos presentes em ambas as ocasiões pelos debates que muito contribuíram na confecção do texto. Pude ainda contar com leituras e apontamentos fundamentais de Lucas Keese dos Santos, Joana Cabral de Oliveira, Daniel Pierri, Geraldo Andrello, Lígia Rodrigues de Almeida, Rodrigo Brusco e Diogo Henrique Cardoso. Eximidos de qualquer responsabilidade por equívocos no artigo ou de concordarem com seus argumentos, agradeço-lhes pelas misturas que tanto enriqueceram sua composição.

1 Alterei a grafia usada por Schaden, adaptando-a à grafia mais usual entre os Guarani na região Sudeste, critério também adotado nas demais expressões guarani ao longo do texto. Minha tradução do trecho tampouco é idêntica à de Schaden $(1974: 158)$

2 Com o termo modulação, busco evitar a circunscrição de fronteiras étnicas aos Guarani e ao mesmo tempo remeter a singularidades pelas quais se conectam e se diferenciam de outros ameríndios. Inspiro-me aqui no que Goldman (2005) formulou como modulações do axé entre orixás e entre iniciados no candomblé, remetendo a um processo simultâneo de concretização, diversificação e individuação de relações.

3 O mapa resulta do trabalho conjunto de instituições em diferentes países, vinculados à Campanha Guarani: http://campanhaguarani.org/guaranicontinental/\# (acessado em 09/07/2017).

4 Neste texto, não utilizo hífen na designação Tupi Guarani para diferenciá-la da família linguística Tupi-Guarani, tal como propõe Danaga (2016a, 2016b).

5 A maioria das palavras em guarani é oxítona. Neste artigo, seguindo a grafia preferencial dos Guarani em São Paulo, optei por não acentuar as oxítonas, tal como mbya, tampouco as paroxítonas, como nhandeva.

6 Em razão da circulação de pessoas e famílias em aldeias no sul e sudeste do país, elas contam com significativa oscilação populacional.

7 Nhande: nós inclusivo; va'e: nominalizador; kuery: coletivizador.

8 Buscando desessencializar etnônimos indígenas, Viveiros de Castro (1996) reconheceu-os como pronomes cosmológicos, por expressarem não fronteiras identitárias, mas posições em relações de alteridade, sempre em movimento e transformação.

9 Afectivo ou afecção são expressões a que recorro neste artigo aproximando-me do sentido que lhes confere Spinoza (2013 [1677]:107-113, II Parte, Proposições 16 a 19), como aquilo que experimenta um corpo sob efeito de outro(s), investindo-o de modos singulares de afetar e ser afetado, ou potências. Ainda com Spinoza, um corpo não resulta de uma composição de partes, e sim de uma individuação de movimentos e repousos acionados por outros, por sua vez também acionados e compostos por outros (Spinoza 2013: 99, 105) 
10 O conceito de cosmopolítica é aqui incorporado a partir da inflexão proposta por Sztutman (2012) - em diálogo com a cosmopolítica nas proposições de Stengers (2007) e Latour (2007), problematizando a premissa estruturante da modernidade ocidental da política como domínio da agência e diversidade humana, em contraste com uma natureza dada e universal - ao voltar-se para os mundos ameríndios e sua multiplicidade de agenciamentos políticos envolvendo sujeitos que não compartilham uma mesma humanidade.

11 Em diálogo com proposições spinozistas e bergsonianas, Deleuze e Guattari (1997 [1981]) conceituam limiar de intensidade como composição relacional cuja individuação não é extensiva, e sim por sua potência afectiva.

12 Estética considerada no sentido stratherniano (2006), como formas relacionais implicadas na produção de certos efeitos, a partir de um universo convencional compartilhado.

13 Narrativas sobre sua descendência dos Tupi quinhentistas circulam nas aldeias de maioria tupi guarani em São Paulo, sendo abordadas nas etnografias de Macedo (2009, 2016), Mainardi (2014), Almeida (2016) e Danaga (2016a, 2016b).

14 Efeitos patogênicos de casamentos com brancos são extensamente tematizados na etnologia guarani, associados ao sangue e à incompatibilidade das almas (Ladeira 2007; Pissolato 2007; Macedo 2009, 2013; Heurich 2011; Pierri 2013; Ramo y Affonso 2014; Testa 2014 etc.).

15 Sobre os xondaro, ver Macedo (2012, 2017); Santos (2016) etc.

16 Sáez se vale aqui do conceito de Deleuze e Guattari (1997) mencionado na nota 11, em que intensivo diz respeito a um limiar de intensidade, cuja individuação não se dá pela forma, mas pelas potências em jogo na composição relacional.

17 O autor é um expoente dessa chave teórica, definindo sua abordagem como "uma visão funcionalista dos processos aculturativos" (1974:1).

18 Ficaram um tempo na aldeia do Itariri e posteriormente seriam os formadores da aldeia Rio Comprido. Nos anos 1950, fundariam outro aldeamento às margens do Ribeirão Silveira, onde faleceria seu karai. Em décadas seguintes, sob liderança de sua esposa Maria Tatatĩ, esse coletivo formaria várias outras aldeias ao longo da costa litorânea até o Espírito Santo (Ciccarone 2001; Ladeira 2007; Macedo 2009 etc.).

19 Há uma extensa bibliografia abordando nhe'ẽ, a exemplo de Cadogan (1959), Clastres (1978, P. Clastres 1990), Ladeira (2007), Pissolato (2007), Macedo (2009), Heurich (2011), Pierri (2013), Macedo \& Sztutman (2014), Ramo y Affonso (2014), Pereira (2014), Testa (2014), Santos (2016) etc. Não há espaço para destrinchar o tema, mas a literatura expressa variações sobre os componentes da pessoa segundo os Guarani, havendo menções a um, dois, três ou múltiplos nhe'ẽ. Em meio a essas variações, entretanto, é comum o reconhecimento do nhe'ẽ porã como aquele que estabelece a conexão com as moradas celestes dos imortais. 
20 Sobre a cartografia cósmica guarani-mbya, ver Cadogan (1959), Ladeira (2007), Pierri (2013).

21 Segundo algumas etnografias, há guaranis que dizem que o nhe'ẽ porã vincula-se ao sujeito, mas nunca deixa de habitar sua morada celeste (Pereira 2014; Santos 2016). Esta não é uma concepção consensual, e mesmo esses autores apontam que o "alto" talvez seja antes um ponto de vista do que uma distância espacial.

22 Cherobim (1986:24) compartilha com Schaden a ênfase teórica em "processos aculturativos", baseando-se ainda no conceito de integração elaborado por Darci Ribeiro.

23 Tal duplicidade experimentada no corpo e as socialidades que engendram aproximam-se do que descrevem etnografias mencionadas posteriormente (Vilaça 2007; Nunes 2013; Kelly 2016).

24 Viveiros de Castro destaca, porém, como tal consanguinização constitui um eufemismo ou um mascaramento da alteridade e perigo intrínsecos aos afins, ou a quaisquer alianças (2015:203).

25 Sobre ritual de nominação, vinculado ao assentamento do nhe'ẽ, ver Macedo (2009), Macedo \& Sztutman (2014), Ramo y Affonso (2014) etc. Sobre relação entre pessoa e $n h e^{\prime} \tilde{e}$, ver também Cadogan (1959), Ladeira (2007), Pierri (2013), Pereira (2014), Santos (2016) etc.

26 Segundo postulado de Spinoza: "O corpo humano pode ser afetado de muitas maneiras, pelas quais sua potência de agir é aumentada ou diminuída, enquanto outras tantas não tornam sua potência de agir nem maior nem menor" (2013:163). A alegria corresponde a uma paixão - sofrer efeito de outros - que aumenta a potência de agir do corpo, já a tristeza constitui efeito inverso, diminuindo a potência de agir (:177). O autor reconhece alegria, tristeza e desejo como afetos primários, dos quais derivam quaisquer outros. Por sua vez, "o desejo é a própria essência do homem, enquanto esta é concebida como determinada, em virtude de uma dada afecção qualquer de si própria, a agir de alguma maneira" (:237)

27 Afinidade potencial, ou virtual, é como Viveiros de Castro $(2007,2015)$ formula a ordem intensiva de relações sintético-disjuntivas entre "parceiros no jogo cósmico do roubo e do dom" (2015:205), os quais não são, ou não deveriam ser afins efetivos, como é o caso de espíritos, deuses, animais e eventualmente os brancos ou outras gentes. Mesmo entre afins efetivos, porém, o autor sugere que a diferença potencial entre os parceiros jamais é nula, em função do estatuto dado de um fundo infinito de alteridades a partir das quais se constrói a consanguinidade e outras relações, sendo "a similitude um caso particular da diferença".

28 Expressão que, como supramencionado, pode ter outros sentidos, como "saudade" e "infelicidade".

29 Sobre tekoaxy, ver também Pissolato (2007), Ramo y Affonso (2014) etc. 
30 "O corpo humano compõe-se de muitos indivíduos (de natureza diferente), cada um dos quais é também altamente composto. [...] Os indivíduos que compõem o corpo humano e, consequentemente, o próprio corpo humano, são afetados pelos corpos exteriores de muitas maneiras" (Spinoza 2013:105). Por essas afecções é que concebemos os corpos exteriores, ou experimentamos o mundo (:119). Assim, padecemos, ou somos seres da paixão, porque nossa existência não existe por si mesma, sendo suscetível às afecções (:273).

31 "Chamamos de bem ou mal aquilo que estimula ou refreia a conservação de nosso ser, isto é, aquilo que aumenta ou diminui, estimula ou refreia nossa potência de agir. Assim, é à medida que percebemos que uma coisa nos afeta de alegria ou de tristeza que nós a chamamos de boa ou má" (Spinoza 2013:277).

32 Entre inúmeros exemplos de tais incorporações, há uma publicação que reúne textos de jovens mbya sobre a preparação dos corpos dos xondaro, a qual pode incluir a captura de abelhas durante a lua nova. A mamágava pode ser capturada - mas não morta, devendo ser solta depois - para que pique a sobrancelha de seu captor, aguçando sua visão e agilidade. Já a kyre'ymba pode ativar a agilidade da criança que receber picadas no joelho (CTI 2013:25). Por sua vez, Vera Mirĩ, no Silveira, contou-me que havia crianças cujos corpos eram preparados com ervas e gordura de onça (Macedo 2012). Em outro exemplo, capacidades relativas à fala - expressão por excelência do nhe'ẽ de origem celeste - também podem ser ampliadas por incorporações envolvendo animais e plantas. Aka'ẽ, morador de uma aldeia na capital paulista, ensinou-me que para uma criança falar bem pode-se capturar um grilo na lua nova, submergi-lo em água morna e depois soltá-lo, dando à criança a infusão. Já o tembeta - em que se perfura o queixo dos rapazes cuja voz está engrossando com o talo enrijecido pelo fogo de uma folha de palmeira pindo, para depois inserir uma haste de takuarembo ou outra cana - é destacado por Aka'ẽ como um recurso para que seja mais moderado nas falas e no comportamento. 
ALMEIDA, Lígia Rodrigues. 2016. Estar em movimento é estar vivo. Territorialidade, pessoa e sonho entre famílias tupi guarani. Tese de Doutorado, PPGAS-USP.

BRUSCO, Rodrigo. 2016. "Comparando parentescos: sobre casamentos com índios e não índios por coletivos tupi guarani e mbya". Jornada de Antropologia-USP, (paper). Mimeo.

CADOGAN, León. 1959a. Ayvu Rapyta. Textos míticos de los Mbyá-Guaraní del Guairá. São Paulo: FFLCH-USP. . 1959b. "Como interpretan los Chiripá (Avá-Guarani) la danza ritual". Revista de Antropologia, $7(1): 64-83$

CENTRO DE TRABALHO INDIGENISTA (coord.). 2013. Xondaro mbaraete. A força do xondaro. São Paulo: CTI.

CHEROBIM, Mauro. 1986. Os índios guarani do litoral do estado de São Paulo. São Paulo: FFLCH/USP.

CICCARONE, Celeste. 2001. Drama e sensibilidade: Migração, xamanismo e mulheres mbya-guarani. Tese de Doutorado, PUC-SP.

CLASTRES, Hélène. 1978. Terra sem mal. O profetismo tupi-guarani. São Paulo: Brasiliense.

CLASTRES, Pierre. 2003 [1974]. A sociedade contra o Estado. São Paulo: Cosac Naify.

1990 [1974]. A fala sagrada: mitos e cantos dos índios guarani. Campinas: Papirus.

DANAGA, Amanda. 2016a. Encontros, efeitos e afetos. Discursos de uma liderança tupi guarani. Tese de Doutorado, PPGAS-UFSCAR.

2016b. "Nome e relações. A noção de mistura entre famílias tupi guarani no litoral paulista". In: A. C. Danaga \& E. A. Peggion (orgs.), Povos indígenas em São Paulo. Novos olhares. São Carlos: UFSCar. pp. 227-247.
DELEUZE, Gilles; GUATTARI, Felix. 1997 [1981]. "10.1730-Devir-intenso, Devir-animal, Devir-imperceptível". In: Mil platôs. Vol. 4. São Paulo: Editora 34. pp. 8-99.

DOOLEY, Robert. 2006. Léxico guarani-dialeto mbyá. Brasília: SIL.

FAUSTO, Carlos. 2005. "Se Deus fosse jaguar: canibalismo e cristianismo entre os Guarani (séculos XVI-XX)". Mana. Estudos de Antropologia Social, 11(2):385-418.

GARLET, Ivori. 1997. Mobilidade mbya: história e significação. Dissertação de Mestrado, PUC-RS.

GOLDMAN, Marcio. 2015. "'Quinhentos anos de contato': Por uma teoria etnográfica da (contra)mestiçagem". Mana. Estidos de Antropologia Social, 21(3):641-659.

2005. "Formas do saber e modos do ser: observações sobre multiplicidade e ontologia no candomblé". Religião e Sociedade, 25(2):102-120.

HEURICH, Guilherme. 2011. Outras alegrias. Parentesco e festas mbya. Dissertação de Mestrado, PPGAS-UFRJ-MN.

LADEIRA, Maria Inês. 2007. O caminhar sob a luz. O território mbya à beira do oceano. São Paulo: Unesp.

.; WERA TUPÃ, Leonardo. 2004.

"Condições ambientais do território guarani: implicações no modo de vida". Tellus, 6(1):51-63.

. AZANHA, Gilberto. 1988. Os Índios da Serra do Mar. A presença Mbyá-Guarani em São Paulo. São Paulo: CTI.

LATOUR, Bruno. 2007. "Quel cosmos? Quelles cosmopolitiques". In: Lolive \& Soubeyran (eds.), L'émergence des cosmopolitiques. Paris: Éditions La Découverte. pp. 69-84. 
KELLY, José. 2016. Sobre a antimestiçagem. Florianópolis: Cultura \& Barbárie.

MACEDO, Valéria. 2009. Nexos da diferença. Cultura e afecção em uma aldeia guarani na Serra do Mar. Tese de Doutorado, PPGAS-USP.

. 2012. "Vetores Porã e Vai na cosmopolítica guarani". Tellus, 21(1):2552.

. 2013. "De encontros nos corpos guarani". Ilha - Revista de Antropologia, 15(1):181-210.

2016. "Uma história de muitas histórias: Trajetórias guarani no curso do Rio Silveira (Serra do Mar)". In: A. C. Danaga \& E. A. Peggion (orgs.), Povos indígenas em São Paulo. Novos olhares. São Carlos: UFSCar. pp. 107-135.

. 2017. "Guarani cosmopolitics in the world of paper". In: Virtanen \& Weber (eds.), Creating dialogues. Indigenous perceptions and changing forms of leadership in Amazônia. Boulder: University Press of Colorado. pp. 127-151.

.; SZTUTMAN, Renato. 2014. "A parte de que se é parte. Notas sobre individuação e divinização (a partir dos Guarani)". Cadernos de Campo, 23(1):287-302.

MAINARDI, Camila. 2014. Desfazer e refazer coletivos. O movimento tupi guarani. Tese de Doutorado, PPGAS-USP.

MELLO, Flávia. 2007. “Mbyá e Chiripá: identidades étnicas, etnônimos e autodenominações entre os Guarani do Sul do Brasil". Tellus, 7(12):49-65.

MENDES, Rafael. 2009. Os animais são muito mais que algo somente bom para comer. Dissertação de Mestrado, PPGAS-UFF.

MONTOYA, Antonio. 1639. Tesoro de la lengua guarani. Madrid: Juan Sanchez.
NIMUENDAJU, Curt. 1987. Lendas da criação e destruição do mundo como fundamentos da religião apapocúva-guarani. São Paulo: Hucitec/Edusp. NUNES, Eduardo. 2013. "Socialidades alternativas: sobre o conceito de cultura dos Karajá de Buridina". Arquivos-CMD, 1(1):92-112.

PEREIRA, Vicente Cretton. 2014. Aqueles que Não Vemos: Uma Etnografia das Relações de Alteridade entre os Mbya-Guarani. Tese de Doutorado, PPGAS-UFF.

PIERRI, Daniel. 2013. O perecível e o imperecível: lógica do sensível e corporalidade no pensamento guarani-mbya. Dissertação de Mestrado, PPGAS-USP.

; BARBOSA, Pablo; BARBOSA, Marco-Antônio. 2013. "Cartas guarani. O uso presente de papéis do passado". Corpus, 39(1):1-9.

PISSOLATO, Elizabeth. 2007. A duração da pessoa. Mobilidade, parentesco e xamanismo mbya. São Paulo: Unesp/ ISA/NuTI.

RAMO Y AFFONSO, Ana. 2014. De pessoas e palavras entre os Guarani-Mbya. Tese de Doutorado, PPGAS-UFF.

SÁEZ, Oscar Calavia. 2016. "Nada menos que apenas nomes: os etnônimos seriais no sudoeste amazônico". Ilha - Revista de Antropologia, 18(2):149176.

SANTOS, Lucas Keese. 2016. A esquiva do Xondaro: movimento e ação política entre os Guarani-Mbya. Dissertação de Mestrado, PPGAS-USP.

SCHADEN, Egon. 1974 [1954]. Aspectos fundamentais da cultura guarani. São Paulo: Edusp.

SEEGER, Anthony; DAMATTA, Roberto; VIVEIROS DE CASTRO, Eduardo. 1979. "A construção da pessoa nas sociedades indígenas brasileiras." Boletim do Museu Nacional, 32(1):2-51. 
SILVEIRA, Nádia. 2011. Imagens de abundância e escassez: comida guarani e transformações na contemporaneidade. Tese de Doutorado, UFSC. SPINOZA, Benedictus. 2013 [1677]. Ética. Belo Horizonte: Autêntica.

STENGERS, Isabelle. 2007. "La proposition cosmopolitique". In: Lolive \& Soubeyran (eds.), L'émergence des cosmopolitiques. Paris: Éditions La Découverte. pp. 45-68.

STRATHERN, Marilyn. 2006. O gênero da dádiva: problemas com as mulheres e problemas com a sociedade na Melanésia. Campinas: Unicamp. SZTUTMAN, Renato. 2012. O profeta e o principal: ação política ameríndia e seus personagens. São Paulo: Edusp.

TEMPASS, Mártin C. 2008. "Comida e gênero entre os Mbyá-Guarani". Caderno Espaço Feminino, 19(1): 287-309.

TESTA, Adriana. 2014. Caminhos de saberes guarani-mbya: modos de criar, crescer e comunicar. Tese de Doutorado, PPGAS-USP.

VEIGA, Juracilda. 2013. "Migrações históricas e cosmologia guarani". $R A U, 5(1): 49-80$.
VILAÇA, Aparecida. 2007. "Cultural change as body methamorphosis". In: Fausto \& Heckenberger (eds.), Time and memory in indigenous Amazonia. Flórida: University Press of Florida. pp. 169-193.

VIVEIROS DE CASTRO, Eduardo. 2015. Metafísicas canibais: elementos para uma antropologia pós-estrutural. São Paulo: Cosac Naify.

. 2007. "Filiação intensiva e aliança demoníaca". Novos Estudos, 77(1):91-126.

. 1996. "Os pronomes cosmológicos e o perspectivismo ameríndio". Mana. Estudos de Antropologia Social, 2(2):115-144.

. 1986. Araweté. Os deuses canibais. Rio de Janeiro: Zahar.

\& TAYLOR, Anne-Christine. 2006. "Un corps fait de regards". In: S. Breton (ed.), Qu'est-ce qu'un corps?. Paris: Musée du Quai Branly/Flamarion. pp. 148-198.

WAGNER, Roy. 2010. A invenção da cultura. São Paulo: Cosac Naify. 
MISTURAR E CIRCULAR EM

MODULAÇÕES GUARANI:

UMA ETIOLOGIA DAS (IN)

DISPOSIÇÕES

\section{Resumo}

Este texto volta-se para pessoas guarani falantes, particularmente aquelas que vivem no estado de São Paulo, em aldeias próximas ou contíguas a centros urbanos e rodovias. Buscando compor uma etiologia guarani das disposições e indisposições dos corpos, remeto a conceituações acerca do que mistura e o que circula entre/em pessoas/gentes, com seus efeitos transformacionais e dimensões fractais. Particularmente, são abordadas indisposições experienciadas como adoecimentos ou como um não se acostumar, que pode vincular-se a um não se sujeitar. A intenção é fazer ressoarem modulações guarani acerca de temas prementes na etnologia ameríndia, como alteridade, afinidade e predação, bem como no debate antropológico mais amplo acerca da mestiçagem e suas premissas concernentes ao diferir.

Palavras-chave: Guarani-Mbya, Tupi Guarani, Afinidade e alteridade, Predação ontológica, Doença, Contramestiçagem, Antimestiçagem.

\author{
MIXING AND CIRCULATING IN \\ GUARANI MODULATIONS: \\ AN AETIOLOGY OF (IN) \\ DISPOSITIONS
}

\section{Abstract}

This article is about Guarani-speaking people, particularly those who live in the state of São Paulo in villages close to urban centres and motorways. Seeking to compose a Guarani aetiology of the dispositions and indispositions of bodies, I turn to conceptualisations of what mixes and what is put into circulation among/in persons/people, with their transformational effects and fractal dimensions. More specifically, the article considers indispositions felt as illness, or as a condition of not getting used to, which may be linked to not being subjected. Its aim is to foreground Guarani modulations on pressing themes in Amerindian ethnology, such as alterity, affinity and predation, as well as on wider anthropological debates on mestijaze and its assumptions concerning differing.

Key words: Guarani-Mbya, Tupi Guarani, Affinity and alterity, Ontological predation, Illness, Counter-mestizaje, Anti-mestizaje. 


\section{MEZCLAR Y CIRCULAR EN \\ MODULACIONES GUARANÍ. UNA ETIOLOGÍA DE LAS (IN) DISPOSICIONES}

\section{Resumen}

Este texto se refiere a personas que hablan guaraní, particularmente aquellas que viven en el estado de São Paulo, en aldeas cercanas o contiguas a centros urbanos y carreteras. Buscando componer una etiología guaraní de las disposiciones e indisposiciones de los cuerpos, remito a conceptualizaciones acerca de lo que mezcla y lo que circula entre/en personas/gentes, con sus efectos transformacionales y dimensiones fractales. En particular, se abordan indisposiciones experimentadas como enfermedades o como un no acostumbrarse, que puede vincularse a un no sujetarse. La intención es hacer resonar modulaciones guaraní acerca de temas apremiantes en la etnología amerindia, como alteridad, afinidad y depredación, así como en el debate antropológico más amplio acerca del mestizaje y sus premisas concernientes al diferir.

Palabras clave: Guaraní-Mbya, Tupi Guaraní, Afinidad y alteridad, Depredación ontológica, Enfermedad, Contramestizaje, Antimestizaje. 